Published in final edited form as:

Nat Immunol. 2010 September ; 11(9): 827-835. doi:10.1038/ni.1913.

\title{
$\lg \mathrm{T}$, a primitive immunoglobulin class specialized in mucosal immunity
}

\author{
Yong-An Zhang ${ }^{1,4}$, Irene Salinas ${ }^{1,4}$, Jun $\mathrm{Li}^{1}$, David Parra ${ }^{1}$, Sarah Bjork ${ }^{2}$, Zhen $\mathrm{Xu}^{1}$, Scott E \\ LaPatra $^{3}$, Jerri Bartholomew ${ }^{2}$, and J Oriol Sunyer ${ }^{1}$ \\ ${ }^{1}$ Department of Pathobiology, School of Veterinary Medicine, University of Pennsylvania, \\ Philadelphia, Pennsylvania, USA \\ ${ }^{2}$ Department of Microbiology, Center for Fish Disease Research, Oregon State University, \\ Corvallis, Oregon, USA \\ ${ }^{3}$ Research Division, Clear Springs Foods, Buhl, Idaho, USA
}

\begin{abstract}
Teleost fish are the most primitive bony vertebrates that contain immunoglobulins. In contrast to mammals and birds, these species are devoid of immunoglobulin A ( $\operatorname{IgA})$ or a functional equivalent. This observation suggests that specialization of immunoglobulin isotypes into mucosal and systemic responses took place during tetrapod evolution. Challenging that paradigm, here we show that IgT, an immunoglobulin isotype of unknown function, acts like a mucosal antibody. We detected responses of rainbow trout IgT to an intestinal parasite only in the gut, whereas IgM responses were confined to the serum. IgT coated most intestinal bacteria. As IgT and IgA are phylogenetically distant immunoglobulins, their specialization into mucosal responses probably occurred independently by a process of convergent evolution.
\end{abstract}

Adaptive immunity first emerged in vertebrates around 550 million years ago along with the appearance of the jawless fish, the most ancient living vertebrate species ${ }^{1}$. In these animals, antigen recognition is mediated by variable lymphocyte receptors ${ }^{2}$. However, these species lack immunoglobulins or $\mathrm{T}$ cell antigen receptors, both of which arose in jawed vertebrates ${ }^{3}$. Throughout evolutionary time, immunoglobulins diversified into several isotypes with

\footnotetext{
Correspondence should be addressed to J.O.S. (sunyer@vet.upenn.edu).

${ }^{4}$ These authors equally contributed to this work.

AUTHOR CONTRIBUTIONS

Y.-A.Z. purified trout IgT, developed polyclonal and monoclonal antibodies to $\operatorname{IgT}$ and a polyclonal antibody to trout pIgR, analyzed the biochemical features of $\operatorname{IgT}$ and the gene-expression profiles of $\operatorname{IgT}^{+}$and $\operatorname{IgM}^{+}$cells, measured specific $\operatorname{IgT}$ and $\operatorname{IgM}$ titers to $C$. shasta and did all experiments involved in cloning and functional studies of trout pIgR; I.S. developed the protocols to obtain leukocytes and bacteria from trout GALT and the immunohistochemistry protocols to detect $\operatorname{IgT}^{+}$and $\operatorname{IgM}^{+}$cells and C. shasta in trout lymphoid tissues and did immunohistochemistry studies and flow cytometry of $\operatorname{IgT}^{+}$and $\operatorname{IgM}^{+}$cells in trout GALT and gut luminal bacteria; J.L. did the flow cytometry of $\operatorname{IgT}^{+}$and $\mathrm{IgM}^{+}$cells of trout lymphoid organs, measured the phagocytotic capacity and intracellular bacterial killing of B cells and contributed to the evaluation of total $\operatorname{IgT}$ and $\operatorname{IgM}$ concentrations in serum and gut mucus, together with Y.-A.Z.; D.P. analyzed IgT and IgM coating on gut bacteria, did the B cell proliferation studies and tested the production of IgT and IgM after stimulation with microbial products; S.B. infected fish with $C$. shasta and provided samples from survivor and control fish; Z.X. contributed to the evaluation of the production of IgT and IgM by cultured trout leukocytes and sorted B cells; S.E.L. and J.B. contributed to the experimental design and discussions related to $C$. shasta infection; J.O.S. designed the overall study, contributed to data analysis and wrote the main body of the paper; and all authors read and commented on the paper. J.L. and D.P. contributed equally to this work.
}

\section{COMPETING FINANCIAL INTERESTS}

The authors declare no competing financial interests.

Accession codes. GenBank: rainbow trout pIgR, FJ940682.

Note: Supplementary information is available on the Nature Immunology website. 
specialized roles in innate and adaptive immunity in the mucosal and systemic compartments ${ }^{3}$. However, it is unclear how and when specialization of immunoglobulin isotypes into systemic and mucosal sites occurred in vertebrates. In mammals and birds, the immunoglobulin M (IgM), IgG and IgY isotypes have a predominant role in systemic responses, whereas IgA is the key participant in mucosal surfaces ${ }^{4,5}$. In contrast, coldblooded vertebrate species lack IgA, although amphibians contain IgX, an isotype expressed mainly in the gut ${ }^{6}$. Teleost fish are the most primitive bony vertebrates that contain immunoglobulins and, in contrast to mammals and birds, they are devoid of $\operatorname{Ig} \mathrm{A}^{3}$ or a functional equivalent of $\operatorname{IgA}$. Thus, there is no evidence of immunoglobulin specialization in teleost mucosal and systemic areas and therefore IgM is regarded as the only functional antibody in both compartments 7,8 . This suggests that specialization of immunoglobulin isotypes into mucosal and systemic responses arose during tetrapod evolution.

The sequencing of several genomes from almost every main class of vertebrate has substantially furthered the understanding of the diversity and evolutionary origins of immunoglobulins. In 2005, a previously unknown immunoglobulin isotype, IgT (also called IgZ), was discovered after analysis of the genomes of several teleost fish species ${ }^{9,10}$. This discovery marked a "sobering moment," 11 as IgT was suggested to represent the final immunoglobulin isotype to be found in vertebrates. Analysis of the locus encoding IgT and IgM heavy chains in trout and zebrafish has showed that although this locus is in a translocon configuration (similar to that of mammalian immunoglobulin heavy-chain loci), its genomic architecture bears a resemblance to that of the locus encoding the $\mathrm{T}$ cell antigen receptor $a$-chain and $\delta$-chain of mammals ${ }^{9-11}$. Such genomic arrangement has allowed the prediction of the existence of two mutually exclusive B cell lineages expressing either IgT or IgM, analogous to the commitment of the T cell lineage into a $\beta$ or $\gamma \delta$ cells. Moreover, the genomic structure of the locus encoding $\operatorname{IgT}$ and $\operatorname{IgM}$ heavy chains rules out possible class-switch recombination events between the genes encoding IgT and IgM. In support of the latter proposal, no evidence has been found of switching of rearranged variablediversity-joining (VDJ) regions between constant $(C)$ regions of genes encoding $\operatorname{IgT}\left(\mathrm{C}_{\tau}\right)$ and $\operatorname{IgM}\left(\mathrm{C}_{\mu}\right)$; instead, use of the $\mathrm{D}$ and $\mathrm{J}$ segments is restricted to the nearby $\mathrm{C}$ regions in all analyzed zebrafish and trout genes encoding $\operatorname{IgT}$ and $\operatorname{IgM}^{9,10}$. In addition, there are no germline $\mathrm{D}_{\tau}$ or $\mathrm{J}_{\tau}$ segments in IgM heavy-chain cDNAs. Moreover, no switch regions similar to those of amphibians, birds or mammals have been found in the teleost sequences analyzed $^{9,10}$.

Thus far, nothing has been reported about the protein structure of $\operatorname{IgT}$ or its distribution and production by putative B cells. More importantly, its function remains an enigma. Here we have characterized $\operatorname{IgT}$ at the protein level and we show that it is a monomeric immunoglobulin in serum. However, in the gut mucus, IgT was chiefly polymeric and was expressed more abundantly there than in serum. Notably, we also provide direct evidence for the existence of a previously unrecognized B cell lineage that expressed only surface IgT. This lineage represented the main B cell subset in the gut-associated lymphoid tissue (GALT) of rainbow trout. More critically, our functional studies indicate that IgT acts like a mucosal intestinal immunoglobulin. Thus, we detected rainbow trout $\operatorname{IgT}$ responses to an intestinal parasite only in the gut, whereas IgM responses were confined to the serum. Moreover, we found that most trout intestinal bacteria were coated with IgT. Our findings collectively indicate the first nontetrapod immunoglobulin specialized in mucosal immunity, to our knowledge. Therefore, our data challenge the present paradigm that specialization of immunoglobulin isotypes into mucosal and systemic responses arose during tetrapod evolution. As IgT and IgA are phylogenetically distant, their specialization into mucosal compartments must have occurred independently by a process of convergent evolution. 


\section{RESULTS}

\section{Protein characterization of serum and gut mucus $\lg T$}

So far, nothing has been reported about the protein structure of IgT. To begin its characterization, we initially raised polyclonal and monoclonal antibodies to rainbow trout IgT (Supplementary Fig. 1), which we used to identify and purify IgT from trout serum. We purified serum IgT by a combination of affinity purification (with an anti-IgT affinity column) and gel-filtration chromatography. The IgT preparation was $>95 \%$ pure, as judged by SDS-PAGE and Coomassie blue staining. Under nonreducing conditions, the molecular mass of IgT was $\sim 180$ kilodaltons $(\mathrm{kDa})$, whereas under reducing conditions, its heavy and light chains had masses of $\sim 75 \mathrm{kDa}$ and $\sim 25 \mathrm{kDa}$, respectively (Fig. 1a). These masses are in close agreement with the theoretical masses obtained from its amino acid sequence ${ }^{9}$. Liquid chromatography-tandem mass spectrometry confirmed that the purified protein corresponded to IgT (Supplementary Fig. 2). Immunoblot analysis showed that the IgTspecific polyclonal antibody (Fig. 1b) and monoclonal antibody (mAb; Fig. 1c, right) reacted specifically with IgT and that an IgM-specific mAb did not recognize IgT (Fig. 1c, left). The molecular mass of purified serum IgT under nonreducing conditions suggested that it could be a monomeric immunoglobulin. Gel-filtration analysis confirmed that hypothesis, showing that serum IgT eluted only at the position expected for a monomer $(\sim 180 \mathrm{kDa})$, as deduced from the standard curve generated with molecular weight standards (Fig. 1d, left). In contrast, most of the IgT present in the gut mucus was in polymeric form, as it eluted at a position similar to that of trout IgM, a tetrameric immunoglobulin ${ }^{12}$ (Fig. 1e, left). However, by SDS-PAGE under nonreducing conditions, gut mucus polymeric IgT migrated as a monomer (Fig. 1e, right), similar to gut or serum monomeric IgT (Fig. 1d,e, right). This finding indicated that the monomeric subunits of gut polymeric IgT are associated by noncovalent interactions. As expected, by SDS-PAGE under nonreducing conditions, serum and gut IgM migrated as a polymer (Fig. 1d,e, right), as most of the IgM subunits are known to be associated through disulfide bonds ${ }^{12}$. We next analyzed the protein concentrations of IgM and IgT in serum and gut mucus and found that whereas the concentration of IgM in serum $(2,520 \mu \mathrm{g} / \mathrm{ml})$ was much higher than that in gut mucus ( 74.9 $\mu \mathrm{g} / \mathrm{ml})$, the concentration of $\operatorname{IgT}$ in gut mucus $(7.1 \mu \mathrm{g} / \mathrm{ml})$ was double that in serum $(3.7 \mu \mathrm{g} /$ $\mathrm{ml}$ ) (Fig. 1f,g). Thus, the ratio of IgT to IgM was 63-fold higher in the gut mucus than in serum (Fig. 1h), which suggested that IgT might have a role in gut mucosal immunity.

\section{Identification of a previously unknown $\lg \mathrm{T}^{+} \mathrm{B}$ cell lineage}

Published studies have demonstrated the occurrence of $\operatorname{IgM}^{-}$leukocytes that express $\operatorname{IgT}$ transcripts ${ }^{13}$. Here we found direct evidence of the existence of a distinct teleost B cell lineage that expressed only surface IgT. The IgT-specific $\mathrm{mAb}$ recognized a population of $\mathrm{IgM}^{-}$cells with typical lymphocyte-like morphology (Fig. 2a). Electron microscopy of sorted $\operatorname{IgT}^{+} \mathrm{B}$ cells showed they had a morphology nearly indistinguishable from that of $\operatorname{IgM}^{+} \mathrm{B}$ cells ${ }^{13}$. Thus, $\operatorname{IgT}^{+} \mathrm{B}$ cells were characterized by a large round nucleus, a thin rim of agranular cytoplasm and a varying number of small dendrites surrounding the cell (Fig. 2a, top right). Gene-expression analysis showed that membrane IgT was expressed only in the $\operatorname{IgT}^{+}$population and that $\operatorname{IgD}$ was expressed only by the $\operatorname{IgM}^{+}$subset. In addition, $\operatorname{IgT}^{+}$cells lacked expression of $\mathrm{T}$ cell-specific genes (those encoding $\mathrm{T}$ cell antigen receptor and $\mathrm{CD} 8$ ), the IgE receptor FceRI $\gamma$ and the receptor for colony-stimulating factor 1, which indicated an absence of contaminating $\mathrm{T}$ cells and monocytes in the sorted $\operatorname{IgT}^{+} \mathrm{B}$ cell population (Fig. 2b). We found the $\mathrm{IgT}^{+} \mathrm{B}$ cell population constituted $\sim 16-28 \%$ of all trout $\mathrm{B}$ cells in the blood, spleen, head kidney and peritoneal cavity (Fig. 2c,d). In contrast, $\operatorname{IgT}^{+}$ B cells represented the main B cell subset (54.3\% of all B cells) in the gut of trout (Fig. 2d). We used immunofluorescence microscopic analysis of the spleen to further substantiate the presence of the uniquely stained $\operatorname{IgT}^{+}$and $\operatorname{IgM}^{+} \mathrm{B}$ cell subsets found by flow cytometry 
(Fig. 2e and Supplementary Fig. 3a, isotype control). These images also confirmed the absence of double-positive $\operatorname{IgT}^{+} \operatorname{IgM}^{+}$cells, in agreement with the data reported above (Fig. 2c). Thus, we demonstrated the existence of a previously unknown B cell lineage that expressed only surface IgT and showed that it represented the main B cell population of trout GALT.

\section{Myeloid and innate features of $\operatorname{lgT}^{+} B$ cells}

To begin to delineate the potential roles of IgT in immunity, we started by evaluating key innate properties of $\operatorname{IgT}^{+} \mathrm{B}$ cells. $\operatorname{IgM}^{+} \mathrm{B}$ cells of teleost fish are highly phagocytic and have intracellular killing abilities ${ }^{13}$. To assess the phagocytic potential of $\operatorname{IgT}^{+} \mathrm{B}$ cells, we incubated peripheral blood leukocytes with fluorescent latex beads and detected phagocytic $\operatorname{IgT}^{+} \mathrm{B}$ cells by flow cytometry with the mAb to IgT. We found a double-positive fluorescence-associated population corresponding to the phagocytic $\operatorname{IgT}^{+} \mathrm{B}$ cell subset (Fig. 3a). In blood (Fig. 3b) and head kidney (data not shown), the percentage of phagocytic $\operatorname{IgT}^{+}$ $\mathrm{B}$ cells was similar to that of $\operatorname{IgM}^{+} \mathrm{B}$ cells. To further assess the degree of bead internalization as well as the ultrastructural features of phagocytic $\operatorname{IgT}^{+} \mathrm{B}$ cells, we sorted these cells and analyzed them by transmission electron microscopy. As expected, the images showed cells with a lymphocyte-like structure (Fig. 3c) identical to that of sorted $\operatorname{IgT}^{+} \mathrm{B}$ cells (Fig. 2a). We found phagocytic $\operatorname{IgT}^{+} \mathrm{B}$ cells containing about one to seven ingested 1$\mu \mathrm{m}$ beads (Fig. $3 \mathrm{c}$ ), and we observed many $\operatorname{IgT}^{+} \mathrm{B}$ cells in the process of internalizing beads through pseudopodia formation (Supplementary Fig. 4). Phagocytosis was inhibited in a dose-dependent manner by cytochalasin B (Fig. 3d), which indicated the involvement of microtubules and microfilaments during the internalization process ${ }^{14}$. In addition to phagocytosing beads, $\operatorname{IgT}^{+} \mathrm{B}$ cells also ingested bacteria (data not shown) and were able to kill them intracellularly, as shown by the time-dependent decrease in the survival rate of ingested bacteria (Fig. 3e).

We next assessed the ability of $\operatorname{Ig} \mathrm{T}^{+}$and $\operatorname{IgM}^{+} \mathrm{B}$ cells to undergo rapid proliferation and to secrete immunoglobulin after being incubated with Vibrio anguillarum bacterin or Escherichia coli lipopolysaccharide. In the presence of the $V$. anguillarum bacterin, head kidney $\operatorname{IgT}^{+}$and $\operatorname{IgM}^{+}$B cells were proliferating by day 3 , although extensive proliferation occurred by day 7 (about five- to sevenfold more than that of control cells; Fig. 4a). As for the production of $\operatorname{IgT}$ and $\operatorname{IgM}$, secretion of both immunoglobulin isotypes was significantly greater in response to treatment with $V$. anguillarum bacterin at day 7 (Fig. $4 \mathrm{~b}, \mathrm{c}$ ). The enhanced secretion of IgT and IgM at day 7 was associated with a greater percentage of large $\mathrm{IgT}^{+}$and $\mathrm{IgM}^{+}$cells in the bacterin-exposed leukocytes (Fig. 4d). The greater size of $\operatorname{IgT}^{+}$and $\operatorname{IgM}^{+}$cells was shown by their greater forward scatter than that of most $\operatorname{IgT}^{+}$and $\mathrm{IgM}^{+} \mathrm{B}$ cells from untreated control samples (Fig. 4d). In support of the aforementioned correlation between the increase in immunoglobulin production and greater size of $\operatorname{IgT}^{+}$and $\operatorname{IgM}^{+}$cells at day 7, we found that sorted large $\operatorname{IgT}^{+}$and $\operatorname{IgM}^{+}$cells had a significantly greater capacity to produce $\operatorname{IgT}$ and $\operatorname{IgM}$, respectively, than did small $\operatorname{IgT}^{+}$and $\operatorname{IgM}^{+}$B cells (Fig. 4e). Treatment of cells with E. coli lipopolysaccharide induced responses similar to those obtained by treatment with $V$. anguillarum bacterin (data not shown). Thus, it seems that both $\operatorname{IgM}^{+}$and $\operatorname{IgT}^{+} \mathrm{B}$ cells have similar phagocytic abilities as well as very similar capacities to proliferate and secrete immunoglobulin in response to microbial stimulation.

\section{IgT responses to a gut parasite restricted to trout GALT}

The observation that $\operatorname{IgT}$ and $\operatorname{IgT}^{+} \mathrm{B}$ cells were prevalent in the gut (Figs. $1 \mathrm{~g}$ and $2 \mathrm{~d}$ ) led us to hypothesize a role for IgT in mucosal immunity. To assess our hypothesis, we evaluated the immune responses of fish infected with Ceratomyxa shasta, a protozoan parasite with considerable tropism for the gut of salmonids ${ }^{15}$. In agreement with published findings ${ }^{15}$, we found that fish that survived 3 months after infection had obvious signs of inflammation in 
the GALT, as shown by extensive leukocytic accumulation in the gut lamina propria (Supplementary Fig. 5). Immunofluorescence microscopy detected the parasite in the gut of all surviving fish analyzed and showed that it was mostly confined to the gut lumen before being excreted in the feces (Fig. 5a-c and d, right). However, there were a few examples in which the parasite was present in the gut epithelium, near the lamina propria (Fig. 5d, left). Notably, immunofluorescence images showed considerable accumulation of $\operatorname{IgT}^{+} \mathrm{B}$ cells in the lamina propria of fish that survived (Fig. 5b). In contrast to uninfected control fish (Fig. $5 a)$, the fish that survived infection had a substantial number of $\operatorname{IgT}^{+} \mathrm{B}$ cells that also permeated the gut epithelium (Fig. 5c, right). In some cases, $\operatorname{IgT}^{+} \mathrm{B}$ cells seemed to be secreting IgT (Fig. 5d). Cell counts of the stained sections showed that surviving fish had $\sim 4.8$-fold more $\operatorname{IgT}^{+}$cells than did control fish (Fig. 6a). We detected the substantial accumulation of $\mathrm{IgT}^{+}$cells in the gut concomitantly with considerably increased ( $\sim 51$-fold)

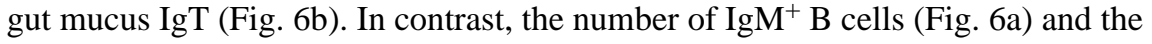
concentration of IgM (Fig. 6b) did not change in the surviving fish. In agreement with the observed greater abundance of $\operatorname{IgT}$ at the protein level, we also found considerable upregulation ( 733-fold) of expression of the gene encoding IgT in the gut of these fish, in contrast to almost negligible upregulation of IgM expression (Fig. 6c).

Notably, the surviving fish had significant titers of parasite-specific IgM in the serum $(\sim 1,264)$, whereas we did not detect IgM titers in the mucus of most fish (Fig. 6d,e). Conversely, we detected titers of parasite-specific IgT only in the gut mucus ( 160) but not in the serum (Fig. 6d,e). These data support the idea that IgT is an immuno-globulin specialized in mucosal immunity.

\section{A large fraction of gut bacteria coated with IgT}

An important property of IgA in the gut of humans is its ability to recognize and coat a large percentage of luminal bacteria ${ }^{5,16}$. This IgA coat is thought to prevent luminal bacteria from attaching and invading the gut epithelium ${ }^{5,17}$. To further support the idea that IgT is involved in gut homeostasis, we tested the hypothesis that like human IgA, IgT coats gut luminal bacteria. For this, we adapted to our fish system a methodology used to assess immunoglobulin coating of human gut luminal bacteria ${ }^{16}$. Flow cytometry showed that most trout gut luminal bacteria stained for IgT $(\sim 48 \%)$, whereas a smaller proportion $(\sim 24 \%)$ was positive for IgM (Fig. 7a-c). Immunofluorescence microscopy substantiated the results obtained by flow cytometry, showing a predominance of bacteria with varying degrees of IgT staining (Fig. 7d-g and Supplementary Fig. 6a-d; isotype-matched control antibody, Supplementary Fig. 6e-h). A smaller portion of the bacteria was stained only for IgM (Supplementary Fig. 6c,d), whereas some bacteria were stained for both IgT and IgM (Fig. $7 \mathrm{~g})$. Immunoblot analysis confirmed further the presence of $\operatorname{IgT}$ and $\operatorname{IgM}$ on these bacteria (Fig. 7h).

\section{Polymeric immunoglobulin receptor in rainbow trout}

In mammals, the transport of polymeric IgA from the mucosal epithelium into the gut lumen is mediated by the polymeric immunoglobulin receptor $(\mathrm{pIgR})^{18,19}$. To understand the basis by which IgT and IgM could be found in the gut mucus, we identified and cloned a rainbow trout pIgR-like molecule (Supplementary Fig. 7; primers, Supplementary Table 1) with a very high degree of sequence similarity and phylogenetic relationship to cloned pIgRs of teleost fish and tetrapods (Fig. 8a and Supplementary Fig. 8). Similar to other teleost $\operatorname{pIgRs}^{20,21}$, the trout pIgR was a type I transmembrane protein consisting of a ligand-binding extracellular region with two immuno-globulin-like domains (Supplementary Fig. 8). Comparison with mammalian pIgR sequences showed that the two trout pIgR immunoglobulin domains corresponded to mammalian pIgR domain 1 (at the amino terminus of trout $\mathrm{PIgR}$ ) and domain 5 . We raised antibodies to recombinantly produced domain 5 of 
trout pIgR (Supplementary Fig. 9) that specifically recognized trout pIgR (Fig. 8b,c). Hence, the antibody to trout pIgR stained only positively transfected Madin-Darby canine kidney (MDCK) cells expressing Flag-tagged trout pIgR (Fig. 8b). In addition, by immunoblot analysis, this antibody reacted with the same protein detected by the Flag-specific $\mathrm{mAb}$ in lysates of cells transfected with trout pIgR (Fig. 8c). The secretory component portion of mammalian pIgR is known to be associated with secretory luminal $\operatorname{Ig} A^{18}$. Using the trout pIgR-specific antibody we detected a trout secretory component-like molecule (tSC) only in the gut mucus, not in the serum (Fig. 8c, left). The molecular mass of the immuno-reactive bands $(\sim 38 \mathrm{kDa})$ was near the theoretical mass obtained from the sequence of trout pIgR, with exclusion of its transmembrane and cytoplasmic domains. To determine whether tSC was associated with $\operatorname{IgT}$ and $\operatorname{IgM}$ of the gut mucus, we did coimmunoprecipitation studies with IgT- or IgM-specific antibodies. Our results showed that anti-IgT and anti-IgM were able to coimmunoprecipitate tSC in association with the immunoprecipitated IgT or IgM (Fig. 8d). Thus, rainbow trout contain a pIgR whose putative secretory component is associated only with gut mucus $\operatorname{IgT}$ and $\operatorname{IgM}$, whereas these immunoglobulins in serum are free of the secretory component.

\section{DISCUSSION}

Immunoglobulins were discovered over a century $\mathrm{ago}^{3}$. The study of immunoglobulins in phylogenetically divergent species has greatly contributed to the understanding of their structure, function and evolutionary origins ${ }^{3}$. The discovery of $\operatorname{IgT} 5$ years ago marked a special moment, as it was proposed that this immunoglobulin might represent the final isotype to be found in vertebrates ${ }^{11}$. So far, its function has remained an enigma. Our studies have identified $\operatorname{IgT}$ as the most ancient reported immunoglobulin specialized in mucosal immunity.

To characterize trout IgT, we generated polyclonal and monoclonal antibodies that allowed its detection and purification from trout fluids. In contrast to tetrameric IgM, IgT existed as monomer in serum. Notably, in the gut mucus, IgT was present for the most part as a polymer, a situation analogous to that of human IgA, which is found in polymeric form in the gut mucus and as a monomer in the serum ${ }^{22}$. This is not the case, however, for several other mammalian species, in which IgA is also present in polymeric form in the serum ${ }^{23}$. Although the tetrameric IgM of teleosts is found in various redox forms that differ in the number of monomeric subunits associated through disulfide bonds ${ }^{12}$, we found that all subunits from polymeric mucus IgT were associated by noncovalent interactions, a property that seems unique to polymeric IgT. Although IgM was by far the prevailing isotype in the serum, IgT concentrations in the gut mucus were double those in serum, which suggested a possible role for $\operatorname{IgT}$ in gut mucosal immunity. Similarly, $\operatorname{IgA}$ is the predominant immunoglobulin isotype in mammalian gut mucosa ${ }^{22}$.

The prevalence of $\operatorname{IgT}$ in the gut mucus led us to hypothesize the existence of an IgT receptor involved in its transport from trout GALT into the gut lumen. We found that rainbow trout have a $\mathrm{PIgR}$ and that its putative secretory component (tSC) was associated with both IgT and IgM in gut mucus, whereas in serum, tSC was absent. This finding supports the idea that like mammalian secretory $\operatorname{Ig} \mathrm{A}$ and $\operatorname{IgM}$, mucosal trout $\operatorname{Ig} \mathrm{T}$ and $\operatorname{IgM}$ need to associate with a pIgR for transport into the gut lumen. These data are in agreement with that of a report on pIgR in fugu, another teleost fish, in which a fragment of the $\mathrm{pIgR}$ is associated with $\operatorname{IgM}^{20}$. However, we were not able to identify a $\mathrm{J}$ chain-like molecule in trout or other teleost fish. This apparent lack of a J chain combined with the absence of disulfide bridges holding together the monomers of polymeric $\operatorname{IgT}$ are the likely reasons polymeric IgT migrated like a monomer in SDS-PAGE under nonreducing conditions. It is worth mentioning that although amphibians have a $\mathbf{J}$ chain, this molecule does not associate 
with $\operatorname{Ig} X^{6}$. Thus, it would seem that the $\mathrm{J}$ chain is not required for the interaction of $\mathrm{pIgR}$ with bony fish immunoglobulins or amphibian IgX.

It was believed that teleost fish have a single B cell lineage characterized by the surface expression of $\operatorname{IgM}^{7}$. In that context, teleost $\mathrm{B}$ cells have been compared with the mammalian B-1 lineage. However, in contrast to the B cells of mammals, the $\mathrm{IgM}^{+} \mathrm{B}$ cells of teleosts are found in very large numbers in the blood and spleen, where they can constitute up to $\sim 20$ $55 \%$ of all leukocytes ${ }^{13,24-26}$. Here we have demonstrated the existence of a previously unrecognized B cell lineage that expressed only surface IgT, thus indicating the presence of two main B cell lineages in trout: one that expresses surface $\operatorname{IgM}$ and another that expresses surface IgT. Thus, our results confirm the predicted and reported exclusive rearrangements, either $\mathrm{V}_{\mathrm{H}} \mathrm{D}_{\tau} \mathrm{J}_{\tau} \mathrm{C}_{\tau}$ or $\mathrm{V}_{\mathrm{H}} \mathrm{D}_{\mu} \mathrm{J}_{\mu} \mathrm{C}_{\mu}$, in the immunoglobulin heavy-chain locus of rainbow trout ${ }^{9}$, which indicates the existence of two mutually exclusive $\mathrm{B}$ cell lineages that express either $\operatorname{IgT}$ or IgM. Given this genomic configuration of the trout immunoglobulin heavy-chain locus, only one immunoglobulin isotype can be expressed at a time in a single B cell. Hence, it would seem that teleosts use a different strategy for generating B cell isotypic diversity than do tetrapods. In addition to the unique $\mathrm{IgT}^{+} \mathrm{B}$ cell population described here, it seems that catfish have an $\operatorname{IgD}^{+} \operatorname{IgM}^{-} \mathrm{B}$ cell subset ${ }^{27}$, which suggests the existence of at least three different $\mathrm{B}$ cell subsets in teleosts.

With the goal of elucidating potential new roles of $\operatorname{IgT}$ in immunity, we initially studied the involvement of the $\operatorname{IgT}^{+} \mathrm{B}$ cell subset in innate immunity. Here we have demonstrated that $\mathrm{IgT}^{+} \mathrm{B}$ cells have potent phagocytic and bactericidal abilities similar to those of the $\operatorname{IgM}^{+} \mathrm{B}$ lineage ${ }^{13}$. It has been suggested that the B cell subset that produces IgT could be the equivalent of mammalian B-1 cell lineage ${ }^{10}$. Here we have shown that the capacity with which both $\operatorname{IgM}^{+}$and $\operatorname{IgT}^{+} \mathrm{B}$ cells proliferated and secreted immunoglobulin in response to microbial stimulation was essentially very similar. Thus, it seems that both trout B cell lineages have important myeloid traits as well as innate features reminiscent of mammalian B-1 cells. However, an important difference between these two B cell lineages is the prevalence of $\operatorname{IgT}^{+} \mathrm{B}$ cells relative to $\operatorname{IgM}^{+} \mathrm{B}$ cells in the gut, which led us to hypothesize the involvement of IgT in intestinal immunity. In support of our hypothesis, we found that the GALT of fish that survived infection with $C$. shasta (a gut parasite) had more $\operatorname{IgT}^{+} \mathrm{B}$ cells, whereas $\operatorname{IgM}^{+} \mathrm{B}$ cell numbers were not greater than those of control fish. Whether this accumulation of $\operatorname{IgT}^{+} \mathrm{B}$ cells was the result of infiltration of cells into the infected area or was the product of local B cell proliferation will require further investigation. Aggregations of $\mathrm{IgA}^{+} \mathrm{B}$ cells in the gut of mammals are observed mainly in secondary lymphoid follicles, including Peyer's patches and mesenteric lymph nodes ${ }^{5,19}$. The histological features of the trout GALT that contained the groups of $\operatorname{IgT}^{+} \mathrm{B}$ cells in the surviving fish did not resemble those of mammalian Peyer's patches or mesenteric lymph nodes, which reinforces the idea that teleost fish lack similar lymphoid follicles in their $\mathrm{GALT}^{8,28,29}$. This indicates that $\operatorname{IgT}$ production in the GALT of trout occurs through extrafollicular pathways. It has become apparent that IgA responses in mammals can also be generated independently of Peyer's patches and mesenteric lymph nodes, although the pathways involved in such responses are not well understood ${ }^{5}$. Thus, it is possible that the extrafollicular pathways of IgA production may be reminiscent of those involved in IgT synthesis in teleost GALT. Hence, future studies of the routes involved in the generation of intestinal IgT in fish will probably aid in the analysis of extrafollicular production of intestinal IgA in mammals.

IgM responses in teleost plasma have been studied extensively and are typically characterized as having high titers in response to infection or vaccination ${ }^{7,30-32}$. However, very few reports exist on teleost IgM responses in the gut, and although results in this area are conflicting, reported gut IgM titers have typically been very $\operatorname{low}^{33}$. Here we found that IgM-specific responses to the parasite were present only in serum, whereas parasite-specific 
IgT titers were confined to gut mucus. These findings demonstrate compartmentalization of the responses of immunoglobulin isotypes into mucosal and systemic areas in response to pathogenic challenge in a cold-blooded vertebrate. Similar IgA-mediated responses to some protozoan parasites in the gut of mammals have been described. For example, $\operatorname{Ig} \mathrm{A}^{+} \mathrm{B}$ cells represent $95 \%$ of all B cells that accumulate in the large intestines of mice infected with the parasite Eimeria falciformis ${ }^{34}$. This parasite is also known to induce higher intestinal $\operatorname{IgA}$ titers $^{35}$.

One of the hallmarks of $\operatorname{IgA}$ in the gut of humans is its ability to coat a large percentage of luminal bacteria. This IgA coating has a key role in immune exclusion at mucosal surfaces $^{5,17}$; thus, the IgA-coated bacteria are prevented from attaching to and invading the gut epithelium ${ }^{5,17}$. Similar to mammalian lumens, the lumens of fish contain high densities of bacteria ${ }^{36}$. We found that the percentage of bacteria coated with IgT was double that of bacteria coated with IgM. These data suggest that IgT and, to a lesser degree, IgM also have a role in immune exclusion. The prevalence of IgT coating in gut bacteria supports further the idea that $\operatorname{IgT}$ is a mucosal immunoglobulin. It is likely that IgT and IgM responses to gut luminal bacteria are $\mathrm{T}$ cell independent. Future studies of fish that have undergone thymectomy may shed light on the aforementioned hypothesis. In amphibians, both IgM and $\operatorname{IgX}$ (but not $\operatorname{IgY}$ ) are expressed in thymectomized animals ${ }^{6}$, which indicates that these immunoglobulins can be produced in a $\mathrm{T}$ cell-independent manner. Therefore, by analogy, IgT and IgM might be present in fish that have undergone thymectomy, although antigenspecific IgT and IgM responses would probably be impaired.

In conclusion, our study has demonstrated unique aspects of the structure and function of IgT that collectively indicate specialization of this ancient immunoglobulin in mucosal immunity. Thus, our findings challenge the present paradigm that specialization of immunoglobulin isotypes into mucosal and systemic responses arose during tetrapod evolution. Notably, although amphibians lack IgA, they contain $\operatorname{IgX}$, an isotype that is unrelated to $\operatorname{IgT}$ or $\operatorname{Ig} \mathrm{A}$ yet is expressed mainly in the gut. We thus propose that the specialization of immunoglobulin isotypes into mucosal and systemic compartments is a canonical feature of all jawed vertebrate immune systems required for the maintenance of immune homeostasis in two main body compartments with very different immune needs. As $\operatorname{IgT}, \operatorname{IgX}$ and $\operatorname{Ig} \mathrm{A}$ are phylogenetically distant, their specialization into mucosal compartments must have occurred independently by a process of convergent evolution driven by similar selective pressures operating on the gut mucosa of teleosts, amphibians and mammals. More particularly, as the gut lumen is rich both in bacterial products derived from commensal bacteria (such as lipopolysaccharide and DNA), as well as food antigens, it is believed that a critical aspect in preserving its mucosal homeostasis relies on mechanisms directed at avoiding or inhibiting acute and chronic inflammatory responses ${ }^{37}$. In this context, secretory IgA is known to be an anti-inflammatory immunoglobulin ${ }^{22,38}$, in contrast to the known proinflammatory abilities of IgM and IgG.

Thus, we predict that a universal property of any intestinal immuno-globulin would be its inability to trigger inflammation in the gut. Consequently, we foresee that mucosal $\operatorname{IgT}$ and IgX probably have anti-inflammatory properties, a hypothesis that needs to be addressed in future studies. Finally, we speculate that all classes of vertebrates must have evolved an antiinflammatory immunoglobulin class or subclass specialized to work in gut mucosal areas. Future comparative studies of mucosal immunoglobulins of species from various phyla will shed light on this hypothesis. 


\section{METHODS}

Methods and any associated references are available in the online version of the paper at http://www.nature.com/natureimmunology/.

\section{Supplementary Material}

Refer to Web version on PubMed Central for supplementary material.

\section{Acknowledgments}

We thank G. Warr (National Science Foundation) for anti-trout IgM; D. Artis and P. Boudinot for critical reading of the manuscript; the Morphology Core of the Center for Molecular Studies in Digestive and Liver Diseases of the University of Pennsylvania, especially G. Swain, for help and advice on immunohistochemistry; C. Pletcher and the staff of the Flow Cytometry and Cell Sorting Facility of the University of Pennsylvania for cell sorting; and Y. Liu, L. Zhang and C. Zhou for technical assistance in cell transfection and immunofluorescence microscopy analyses. Supported by the National Science Foundation (NSF-MCB-0719599 to J.O.S.), the US National Institutes of Health (R01GM085207-01 to J.O.S.) and the United States Department of Agriculture (USDA-NRI 2006-01619 and USDA-NRI 2007-01719 to J.O.S.).

\section{References}

1. Cooper MD, Alder MN. The evolution of adaptive immune systems. Cell. 2006; 124:815-822. [PubMed: 16497590]

2. Alder MN, et al. Antibody responses of variable lymphocyte receptors in the lamprey. Nat. Immunol. 2008; 9:319-327. [PubMed: 18246071]

3. Flajnik MF, Kasahara M. Origin and evolution of the adaptive immune system: genetic events and selective pressures. Nat. Rev. Genet. 2010; 11:47-59. [PubMed: 19997068]

4. Flajnik MF. Comparative analyses of immunoglobulin genes: surprises and portents. Nat. Rev. Immunol. 2002; 2:688-698. [PubMed: 12209137]

5. Cerutti A, Rescigno M. The biology of intestinal immunoglobulin A responses. Immunity. 2008; 28:740-750. [PubMed: 18549797]

6. Mussmann R, Du Pasquier L, Hsu E. Is Xenopus IgX an analog of IgA? Eur. J. Immunol. 1996; 26:2823-2830. [PubMed: 8977274]

7. Solem ST, Stenvik J. Antibody repertoire development in teleosts-a review with emphasis on salmonids and Gadus morhua L. Dev. Comp. Immunol. 2006; 30:57-76. [PubMed: 16084588]

8. Zapata A, Amemiya CT. Phylogeny of lower vertebrates and their immunological structures. Curr. Top. Microbiol. Immunol. 2000; 248:67-107. [PubMed: 10793475]

9. Hansen JD, Landis ED, Phillips RB. Discovery of a unique Ig heavy-chain isotype $(\operatorname{IgT})$ in rainbow trout: Implications for a distinctive B cell developmental pathway in teleost fsh. Proc. Natl. Acad. Sci. USA. 2005; 102:6919-6924. [PubMed: 15863615]

10. Danilova N, Bussmann J, Jekosch K, Steiner LA. The immunoglobulin heavy-chain locus in zebrafsh: identifcation and expression of a previously unknown isotype, immunoglobulin Z. Nat. Immunol. 2005; 6:295-302. [PubMed: 15685175]

11. Flajnik MF. The last fag unfurled? A new immunoglobulin isotype in fsh expressed in early development. Nat. Immunol. 2005; 6:229-230. [PubMed: 15716968]

12. Kaattari S, Evans D, Klemer J. Varied redox forms of teleost IgM: an alternative to isotypic diversity? Immunol. Rev. 1998; 166:133-142. [PubMed: 9914908]

13. Li J, et al. B lymphocytes from early vertebrates have potent phagocytic and microbicidal abilities. Nat. Immunol. 2006; 7:1116-1124. [PubMed: 16980980]

14. Rinehart JJ, Boulware T. Microflament and microtubule function in human monocytes. J. Lab. Clin. Med. 1977; 90:737-743. [PubMed: 561822]

15. Bartholomew JL, Smith CS, Rohovec JS, Fryer JL. Characterization of the host response to the myxosporean parasite, Ceratomyxa shasta (Noble), by histology, scanning electron microscope, and immunological techniques. J. Fish Dis. 1989; 12:509-522. 
16. van der Waaij LA, Limburg PC, Mesander G, van der Waaij D. In vivo IgA coating of anaerobic bacteria in human faeces. Gut. 1996; 38:348-354. [PubMed: 8675085]

17. Stokes CR, Soothill JF, Turner MW. Immune exclusion is a function of IgA. Nature. 1975; 255:745-746. [PubMed: 1169692]

18. Brandtzaeg P. Mucosal immunity: induction, dissemination, and effector functions. Scand. J. Immunol. 2009; 70:505-515. [PubMed: 19906191]

19. Suzuki K, Ha SA, Tsuji M, Fagarasan S. Intestinal IgA synthesis: a primitive form of adaptive immunity that regulates microbial communities in the gut. Semin. Immunol. 2007; 19:127-135. [PubMed: 17161619]

20. Hamuro K, Suetake H, Saha NR, Kikuchi K, Suzuki Y. A teleost polymeric Ig receptor exhibiting two Ig-like domains transports tetrameric IgM into the skin. J. Immunol. 2007; 178:5682-5689. [PubMed: 17442951]

21. Feng LN, et al. Molecular cloning and functional analysis of polymeric immunoglobulin receptor gene in orange-spotted grouper (Epinephelus coioides). Comp. Biochem. Physiol. 2009; 154:282289.

22. Woof JM, Kerr MA. The function of immunoglobulin A in immunity. J. Pathol. 2006; 208:270282. [PubMed: 16362985]

23. Snoeck V, Peters IR, Cox E. The IgA system: a comparison of structure and function in different species. Vet. Res. 2006; 37:455-467. [PubMed: 16611558]

24. Jansson E, et al. Monoclonal antibodies to lymphocytes of rainbow trout (Oncorhynchus mykiss). Fish Shellfsh Immunol. 2003; 14:239-257.

25. Miyadai T, Ootani M, Tahara D, Aoki M, Saitoh K. Monoclonal antibodies recognising serum immunoglobulins and surface immunoglobulin-positive cells of puffer fsh, torafugu (Takifugu rubripes). Fish Shellfsh Immunol. 2004; 17:211-222.

26. Kollner B, Wasserrab B, Kotterba G, Fischer U. Evaluation of immune functions of rainbow trout (Oncorhynchus mykiss) — how can environmental infuences be detected? Toxicol. Lett. 2002; 131:83-95. [PubMed: 11988361]

27. Chen K, et al. Immunoglobulin D enhances immune surveillance by activating antimicrobial, proinfammatory and B cell-stimulating programs in basophils. Nat. Immunol. 2009; 10:889-898. [PubMed: 19561614]

28. Rombout JH, Taverne-Thiele AJ, Villena MI. The gut-associated lymphoid tissue (GALT) of carp (Cyprinus carpio L.): an immunocytochemical analysis. Dev. Comp. Immunol. 1993; 17:55-66. [PubMed: 8449251]

29. Bernard D, et al. Phenotypic and functional similarity of gut intraepithelial and systemic T cells in a teleost fsh. J. Immunol. 2006; 176:3942-3949. [PubMed: 16547228]

30. Bromage ES, Kaattari IM, Zwollo P, Kaattari SL. Plasmablast and plasma cell production and distribution in trout immune tissues. J. Immunol. 2004; 173:7317-7323. [PubMed: 15585855]

31. Zapata A, Diez B, Cejalvo T, Gutierrez-de Frias C, Cortes A. Ontogeny of the immune system of fsh. Fish Shellfsh Immunol. 2006; 20:126-136.

32. Sommerset I, Krossoy B, Biering E, Frost P. Vaccines for fsh in aquaculture. Expert Rev. Vaccines. 2005; 4:89-101. [PubMed: 15757476]

33. Hart S, Wrathmell AB, Harris JE, Grayson TH. Gut immunology in fsh: a review. Dev. Comp. Immunol. 1988; 12:453-480. [PubMed: 3139471]

34. Nash PV, Speer CA. B-lymphocyte responses in the large intestine and mesenteric lymph nodes of mice infected with Eimeria falciformis (Apicomplexa). J. Parasitol. 1988; 74:144-152. [PubMed: 2965760]

35. Rose ME, Peppard JV, Hobbs SM. Coccidiosis: characterization of antibody responses to infection with Eimeria nieschulzi. Parasite Immunol. 1984; 6:1-12. [PubMed: 6608083]

36. Kim DH, Brunt J, Austin B. Microbial diversity of intestinal contents and mucus in rainbow trout (Oncorhynchus mykiss). J. Appl. Microbiol. 2007; 102:1654-1664. [PubMed: 17578431]

37. Garrett WS, Gordon JI, Glimcher LH. Homeostasis and infammation in the intestine. Cell. 2010; 140:859-870. [PubMed: 20303876] 
38. Mason KL, Huffnagle GB, Noverr MC, Kao JY. Overview of gut immunology. Adv. Exp. Med. Biol. 2008; 635:1-14. [PubMed: 18841699]

39. Zhang YA, et al. Conservation of structural and functional features in a primordial CD80/86 molecule from rainbow trout (Oncorhynchus mykiss), a primitive teleost fsh. J. Immunol. 2009; 183:83-96. [PubMed: 19535623]

40. Stocking RW, Holt RA, Foot JS, Bartholomew JL. Spatial and temporal occurrence of the salmonid parasite Ceratomyxa shasta in the Oregon-California Klamath river basin. J. Aquat. Anim. Health. 2006; 18:194-202. 


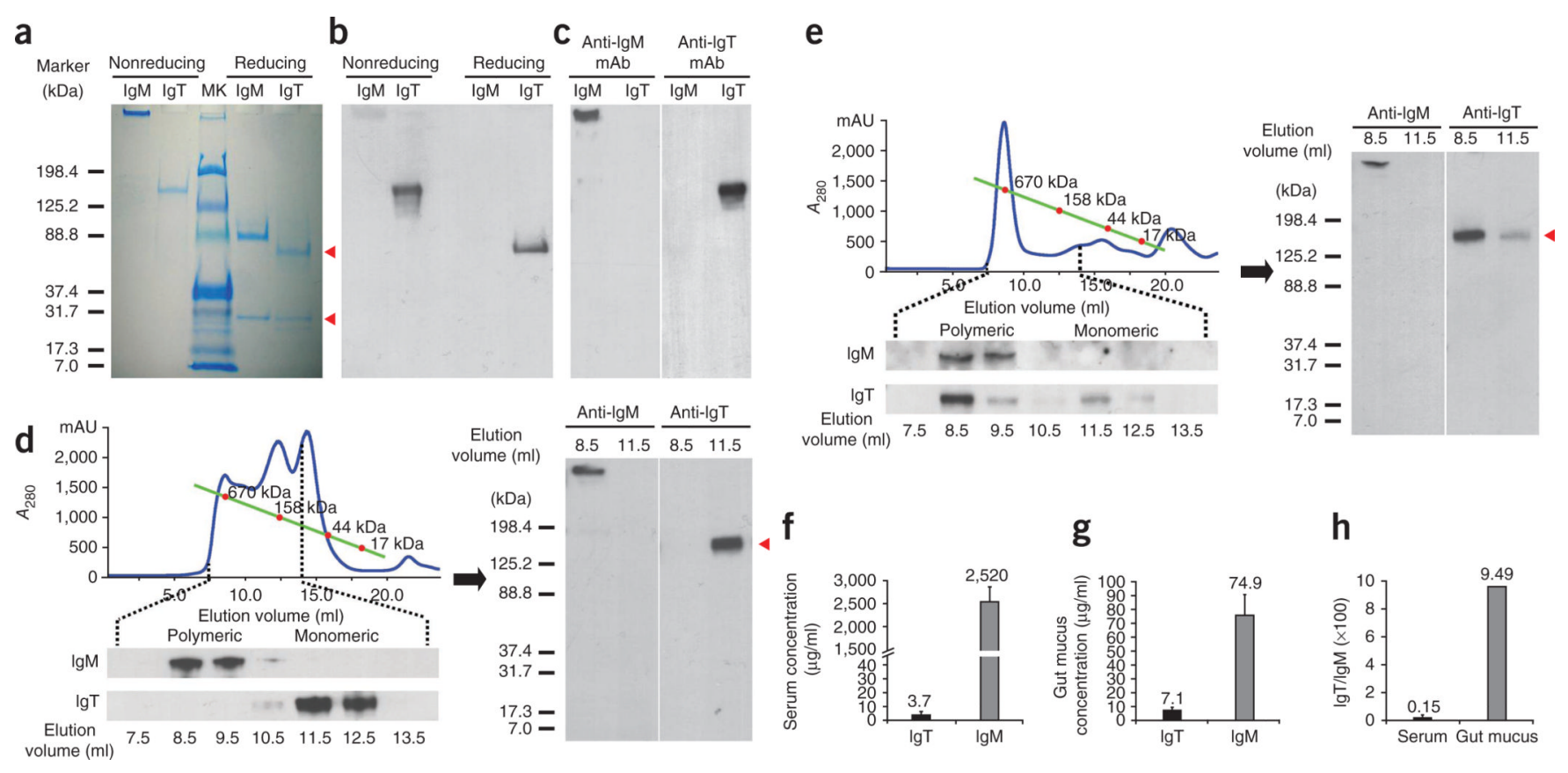

Figure 1.

Purification and structural characterization of IgT. (a) Coomassie blue staining of purified serum IgM and IgT ( $2 \mu \mathrm{g})$ resolved by SDS-PAGE. Red arrowheads indicate heavy and light chains of IgT. Left margin, molecular size in kilodaltons (kDa). (b,c) Immunodetection of $\operatorname{IgM}$ and $\operatorname{IgT}(\sim 0.2 \mu \mathrm{g})$ with a polyclonal antibody (b) and $\mathrm{mAb}(\mathbf{c}$, right $)$ to trout $\operatorname{IgT}$ or an IgM-specific mAb (c, left). (d,e) Fractionation of serum $(0.5 \mathrm{ml}$; d) or gut mucus $(0.5 \mathrm{ml} ; \mathbf{e})$ by gel filtration (top left), followed by immunoblot analysis of the fractions with IgM- and IgT-specific mAbs (below). Right, 4-15\% SDS-PAGE of gel-filtration fractions corresponding to elution volumes of $8.5 \mathrm{ml}$ and $11.5 \mathrm{ml}$ under nonreducing conditions, followed by immunoblot analysis with $\mathrm{mAb}$ to trout IgM or IgT. Red arrowheads indicate monomers. $A_{280}$, absorbance at $280 \mathrm{~nm}$. (f,g) Immunoblot and densitometric analysis of the concentration of $\operatorname{IgM}$ and $\operatorname{IgT}$ in serum (f) and gut mucus (g); $n=10-15$ fish. (h) Ratio of IgT to $\operatorname{IgM}$ in serum and gut mucus, calculated from the values in $\mathbf{f}$ and $\mathbf{g}$. Numbers above bars $(\mathbf{f}-\mathbf{h})$ indicate mean. Data are representative of at least three independent experiments (mean and s.e.m. in $\mathbf{f}, \mathbf{g}$ ). 

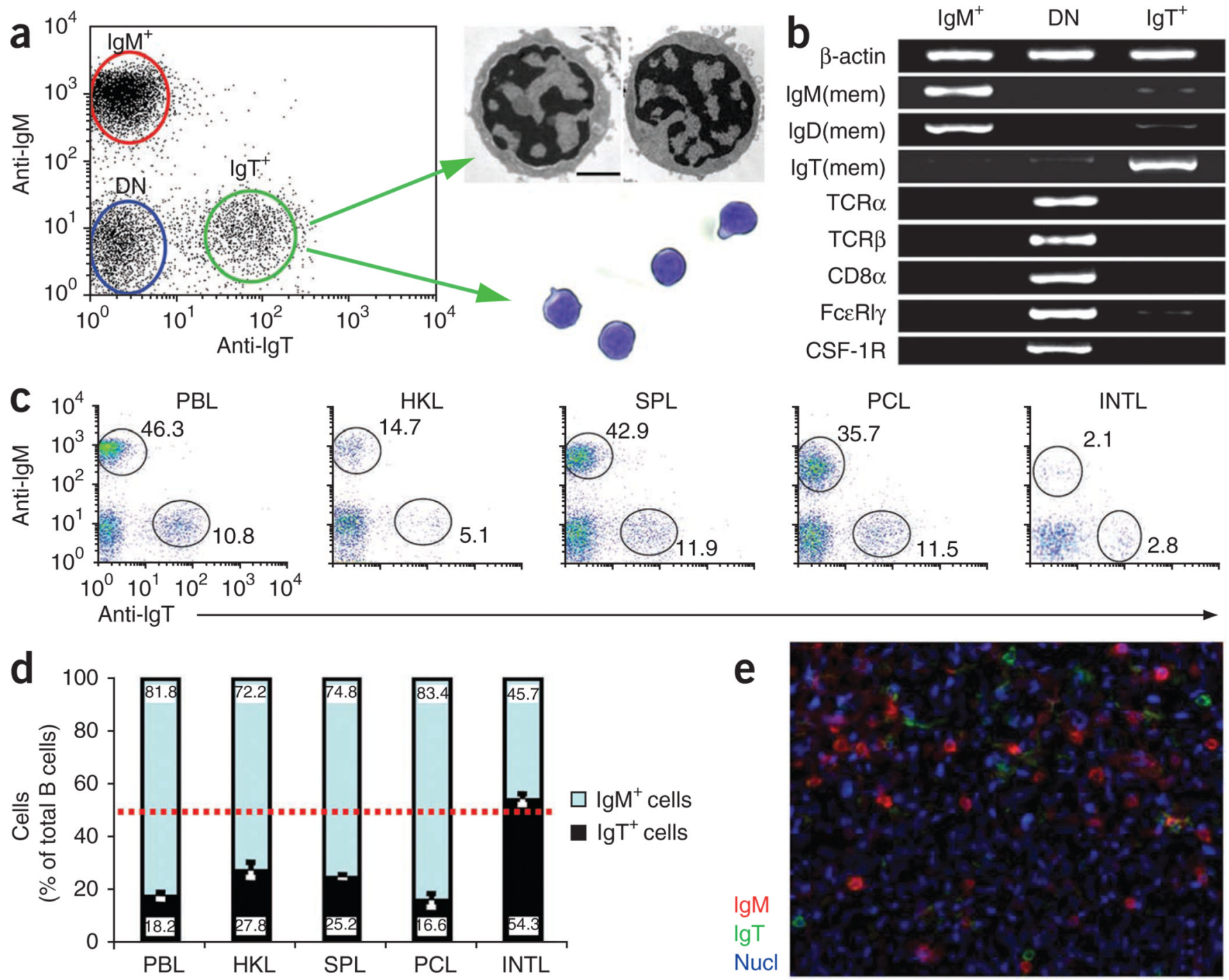

Figure 2.

Identification of a previously unknown B cell lineage that expresses only surface IgT. (a) Flow cytometry (left) of blood leukocytes double-stained with IgM- and IgT-specific mAbs ( $n=5$ fish), and transmission electron microscopy (top right) and Giemsa staining (bottom right) of sorted $\operatorname{IgT}^{+}$B cells. Scale bar, $2 \mu \mathrm{m}$ (top right); original magnification (bottom right), $\times 40$. (b) Gene-expression profiles of sorted $\operatorname{IgM}^{+}$cells, $\operatorname{IgM}^{-} \operatorname{IgT}^{-}$double-negative cells $(\mathrm{DN})$, and $\mathrm{IgT}^{+}$cells among blood leukocytes ( $n=5$ fish). $\beta$-actin, loading control; $\operatorname{IgM}(\mathrm{mem}), \operatorname{IgD}(\mathrm{mem})$ and $\operatorname{IgT}(\mathrm{mem})$, membrane forms of $\operatorname{IgM}, \operatorname{IgD}$ and gT heavy chains; TCRa and TCR $\beta$, T cell antigen receptora- and $\beta$-chains; CSF-1R, receptor for colonystimulating factor 1. (c) Flow cytometry of leukocytes from peripheral blood (PBL), head kidney (HKL), spleen (SPL), peritoneal cavity (PCL) and intestine (INTL). Numbers adjacent to outlined areas indicate percent $\operatorname{IgM}^{+}$cells (top left) or $\operatorname{IgT}^{+}$cells (bottom right). (d) Frequency of $\operatorname{IgM}^{+}$and $\operatorname{IgT}^{+}$cells among total B cells $(n=15$ fish). Red dashed line indicates $50 \%$. (e) Immunofluorescence staining for IgM (red) and IgT (green) in a cryosection of rainbow trout spleen; nuclei (Nucl; blue) are stained with the DNAintercalating dye DAPI (isotype-matched control antibodies, Supplementary Fig. 3a). Original magnification, $\times 20$. Data are representative of at least three independent experiments (mean and s.e.m. in d). 

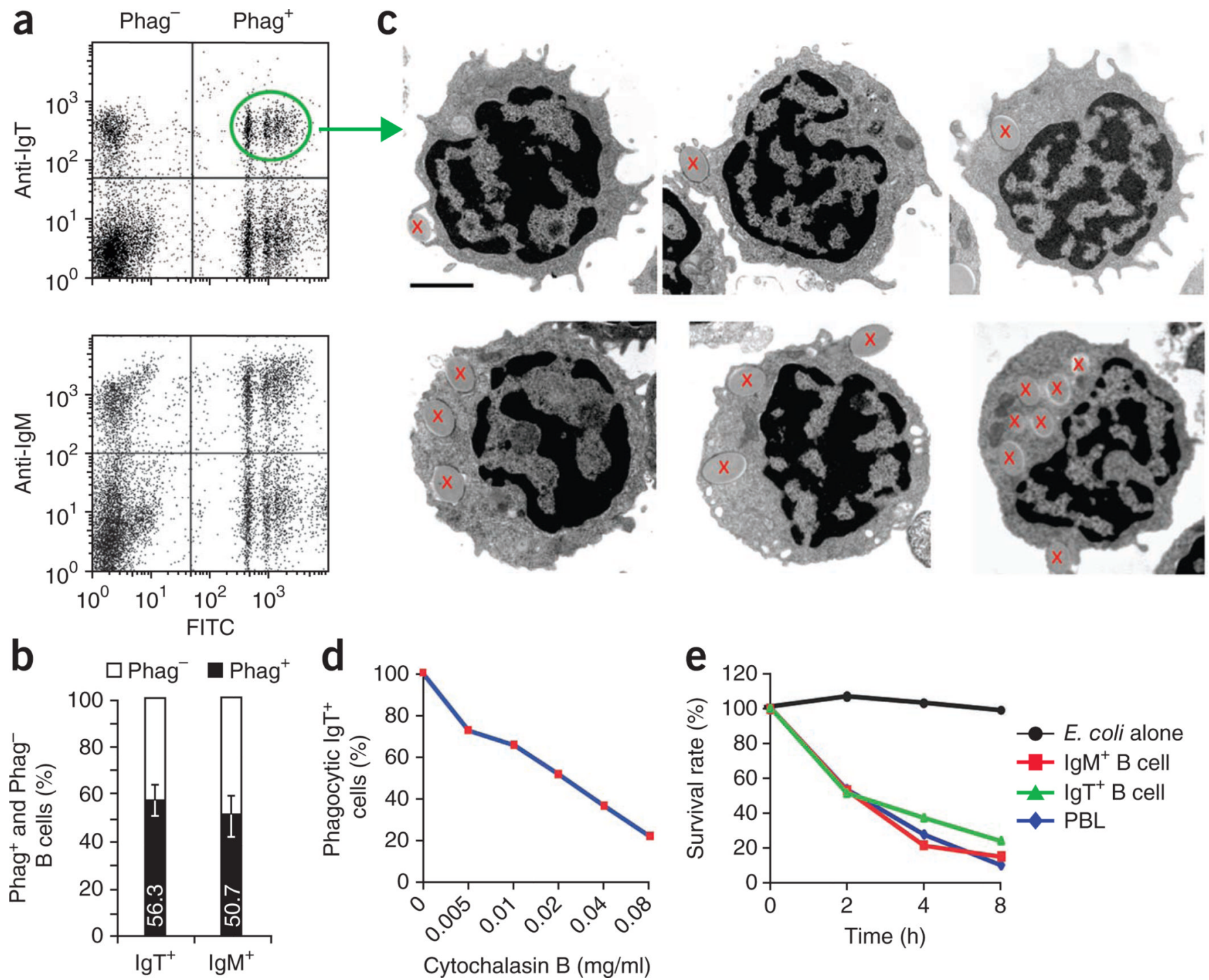

Figure 3.

Phagocytic and intracellular killing capacities of $\operatorname{IgT}^{+}$B cells. (a) Flow cytometry of peripheral blood leukocytes incubated with 1- $\mu$ m fluorescent latex beads (labeled with fluorescein isothiocyanate (FITC)) and then stained with $\mathrm{mAb}$ to trout $\operatorname{IgT}$ or $\operatorname{IgM}(n=9$ fish). $\mathrm{Phag}^{-}$, nonphagocytic; $\mathrm{Phag}^{+}$, phagocytic. (b) Phagocytic and nonphagocytic cells in $\operatorname{IgT}^{+}$or $\operatorname{IgM}^{+} \mathrm{B}$ cell subsets of peripheral blood leukocytes ( $n=9$ fish). Numbers in bars indicate mean percent phagocytic cells. (c) Transmission electron microscopy of various stages of ingestion of $1-\mu \mathrm{m}$ beads (red ' $\mathrm{x}$ ') by phagocytic $\operatorname{IgT}^{+} \mathrm{B}$ cells from peripheral blood leukocytes. Scale bar, $2 \mu \mathrm{m}$. (d) Inhibitory effect of cytochalasin B on the phagocytic capacity of $\operatorname{IgT}^{+} \mathrm{B}$ cells, presented as the percentage of phagocytic cells relative to that of PBS-treated control cells. (e) Intracellular bacterial killing by sorted $\operatorname{IgM}^{+}$and $\operatorname{IgT}^{+} \mathrm{B}$ cells and total peripheral blood leukocytes incubated with live E. coli and lysed; lysates were inoculated onto Luria-Bertani agar plates and surviving intracellular bacteria were counted. Results are presented as percent of live bacteria at time 0 , set as $100 \%$. Data are representative of at least three independent experiments (mean and s.e.m. in b). 

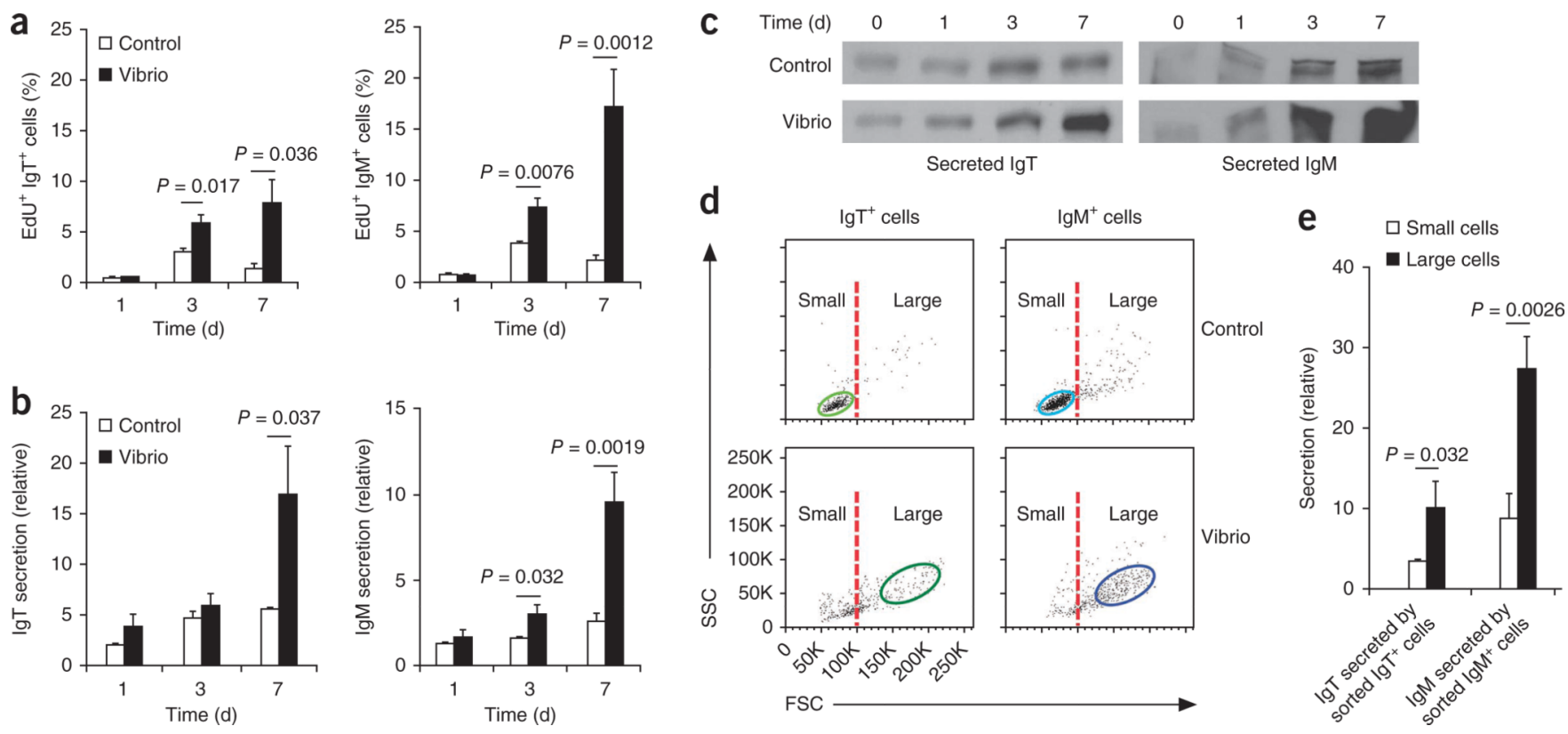

Figure 4.

Proliferative and immunoglobulin-secreting capacities of $\operatorname{IgT}^{+}$and $\operatorname{IgM}^{+}$B cells in response to microbial stimulation. (a) Proliferation of $\operatorname{IgT}^{+}$and $\operatorname{IgM}^{+} \mathrm{B}$ cells among trout head kidney leukocytes left unstimulated (Control) or stimulated for 1, 3 or $7 \mathrm{~d}$ with $V$. anguillarum bacterin (Vibrio), presented as frequency of cells positive for the thymidine analog EdU (5ethynyl-2 $2^{\prime}$-deoxyuridine) in the $\operatorname{IgT}^{+}$or $\operatorname{IgM}^{+}$B cell subset $(n=10-12$ fish). (b) $\operatorname{IgM}$ and IgT in supernatants of cells treated as in $\mathbf{a}$, assessed by immunoblot and densitometric analysis and presented relative to values on day 0 ( $n=6$ fish). (c) Immunoblot analysis of supernatants of cells treated as in a, probed with IgT- and IgM-specific antibodies $(n=6$ fish). (d) Flow cytometry of $\operatorname{IgT}^{+}$and $\operatorname{IgM}^{+}$head kidney leukocytes on day 7 in the presence or absence of $V$. anguillarum bacterin; circles outline the predominant small or large B cell populations. FSC, forward scatter; SSC, side scatter. (e) IgM and IgT in supernatants of head kidney leukocytes collected $7 \mathrm{~d}$ after intraperitoneal injection of a mixture of lipopolysaccharide and $V$. anguillarum bacterin $\left(n=6\right.$ fish), sorted into large and small $\operatorname{IgT}^{+}$ and $\operatorname{IgM}^{+}$cells and cultured for $2 \mathrm{~d}$, assessed by immunoblot and densitometric analysis and presented relative to values at day 0. $P$ values, unpaired Student's $t$-test. Data are representative of three independent experiments (mean and s.e.m. in a,b,e). 
a

Control gut

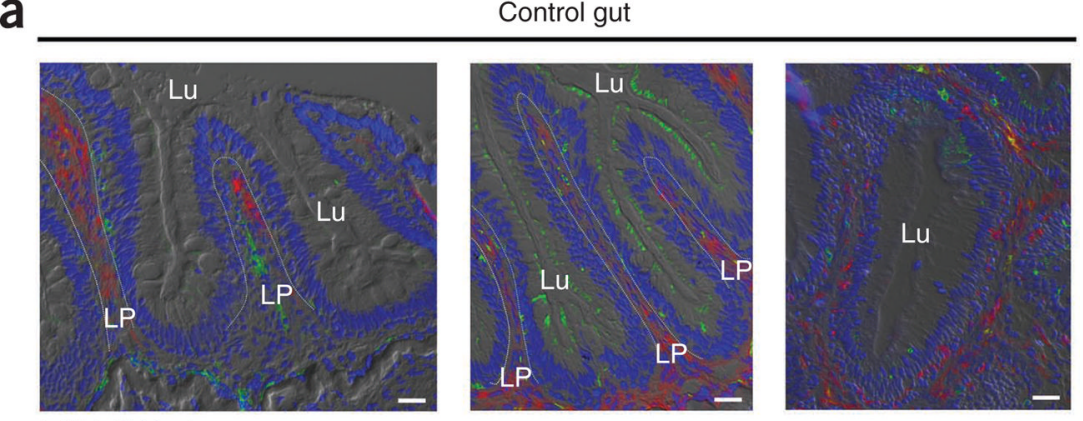

IgM IgT Nucl

Survivor gut
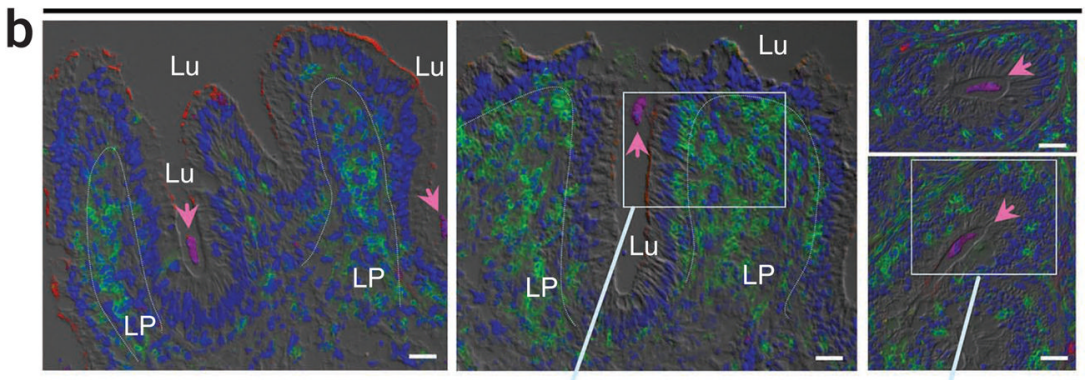

gMig Cer Nucl

C
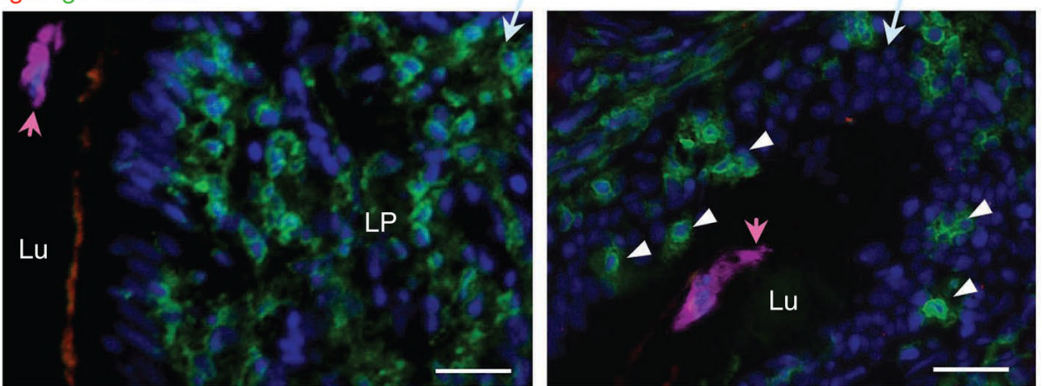

$\operatorname{lgM} \lg \mathrm{T}$ Cer Nucl
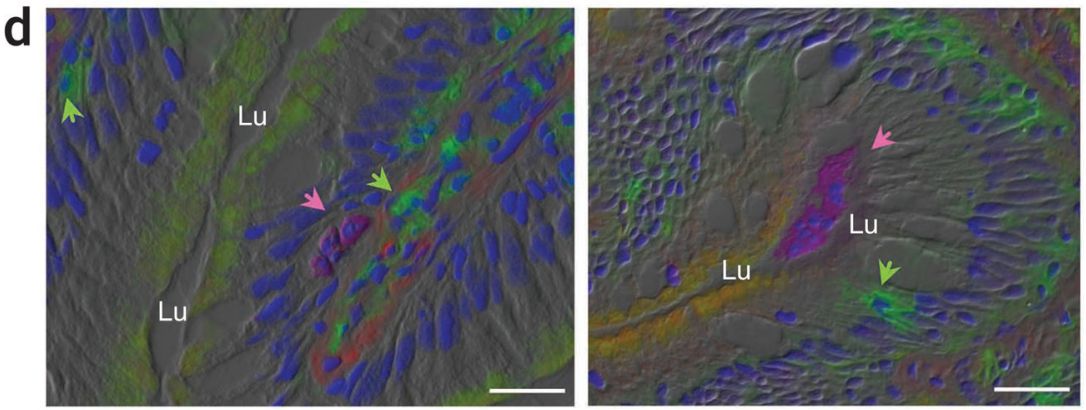

IgM IgT Cer Nuc

Figure 5.

Accumulation of $\operatorname{IgT}^{+} \mathrm{B}$ cells in the GALT of fish that survived infection with $C$. shasta. Differential interference contrast images of immunofluorescence staining of trout gut cryosections from uninfected control fish (a) and fish that survived infection with $C$. shasta (b-d; $n=5$ per group), stained for IgM (red), IgT (green) and C. shasta (Cer; magenta); nuclei are stained with DAPI (isotype-matched control antibody staining, Supplementary Fig. 3b). Blue dotted lines in a,b outline the border of the lamina propria (LP); magenta arrows point to the parasite located in the gut lumen (Lu). (c) Enlarged images of the areas outlined in $\mathbf{b}$, without differential interference contrast, showing infiltrating $\operatorname{IgT}^{+} \mathrm{B}$ cells in 
the gut lamina propria (left) or epithelium (white arrowheads, right). (d) Localization of a parasite in the gut epithelium (left) or lumen (right); green arrows indicate $\mathrm{IgT}^{+} \mathrm{B}$ cells that seem to be secreting IgT. Scale bars, $20 \mu \mathrm{m}$. Data are representative of at least three independent experiments. 

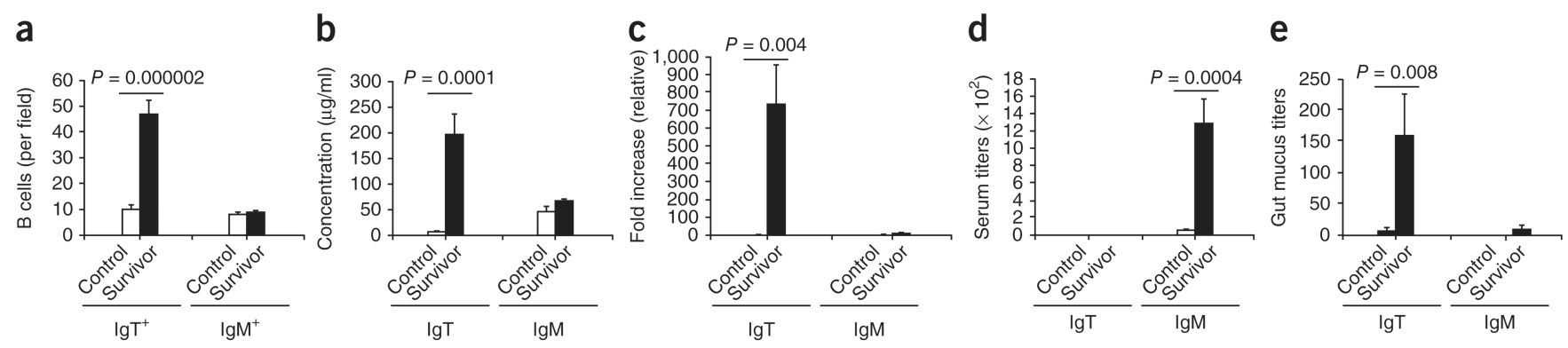

Figure 6.

Immune responses in the gut of trout infected with $C$. shasta are mediated by the IgT system. (a) $\operatorname{IgT}^{+}$and $\operatorname{IgM}^{+} \mathrm{B}$ cells in gut cryosections of uninfected control fish and fish that survived infection with $C$. shasta ( $n=5$ per group), counted in 25 fields (original magnification, $\times 20)$. (b) Gut mucus $\operatorname{IgT}$ and $\operatorname{IgM}(n=9-12$ fish per group). (c) Real-time PCR analysis of IgT and IgM transcripts from the gut, presented relative to expression in control fish, set as 1 ( $n=7$ fish per group). (d,e) ELISA of specific anti-C. shasta IgT and $\operatorname{IgM}$ in the serum (d) and gut mucus (e), presented as end-point titers ( $n=9$ fish per group). $P$ values, unpaired Student's $t$-test. Data are representative of three independent experiments (mean and s.e.m.). 

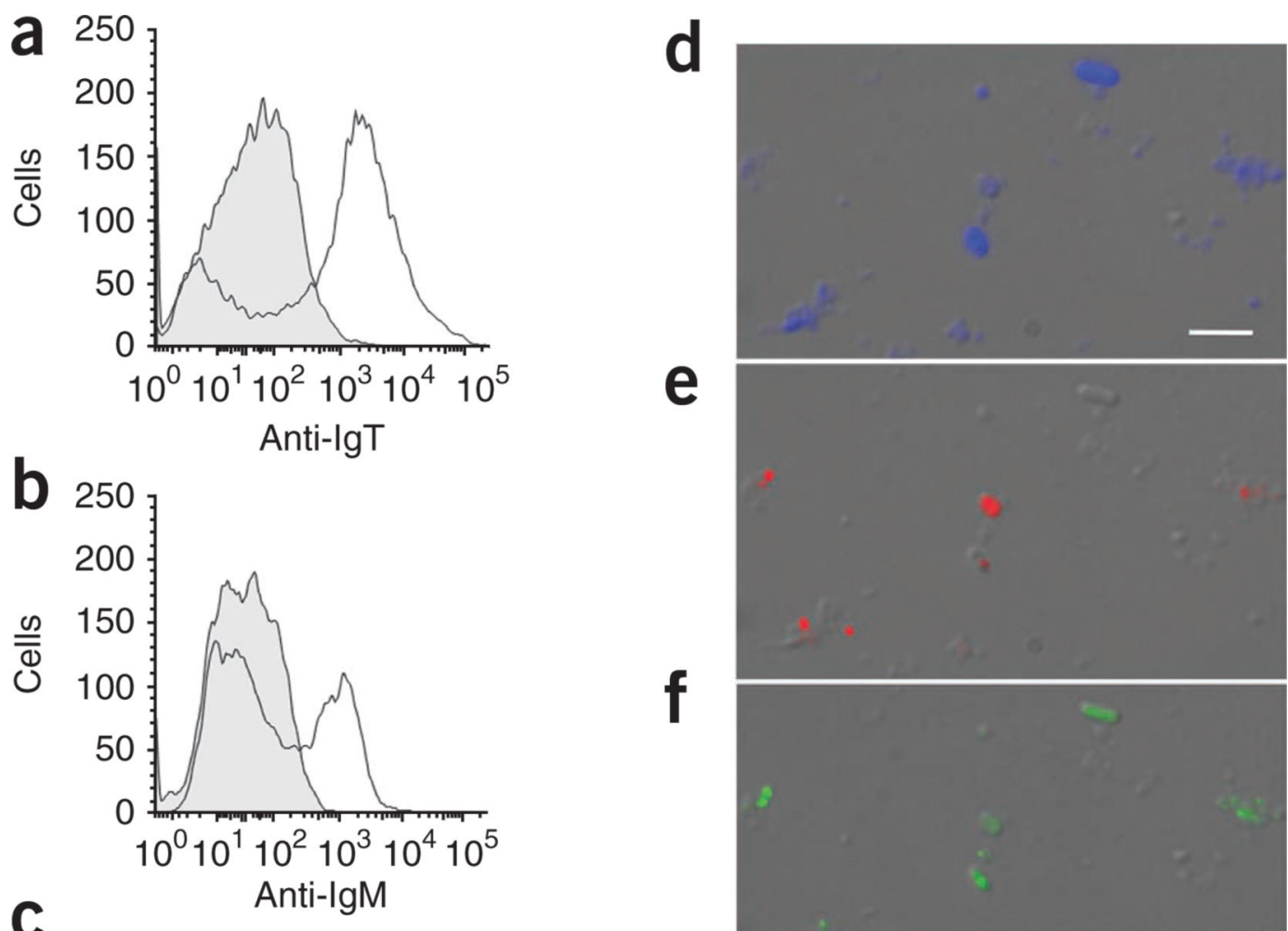

e
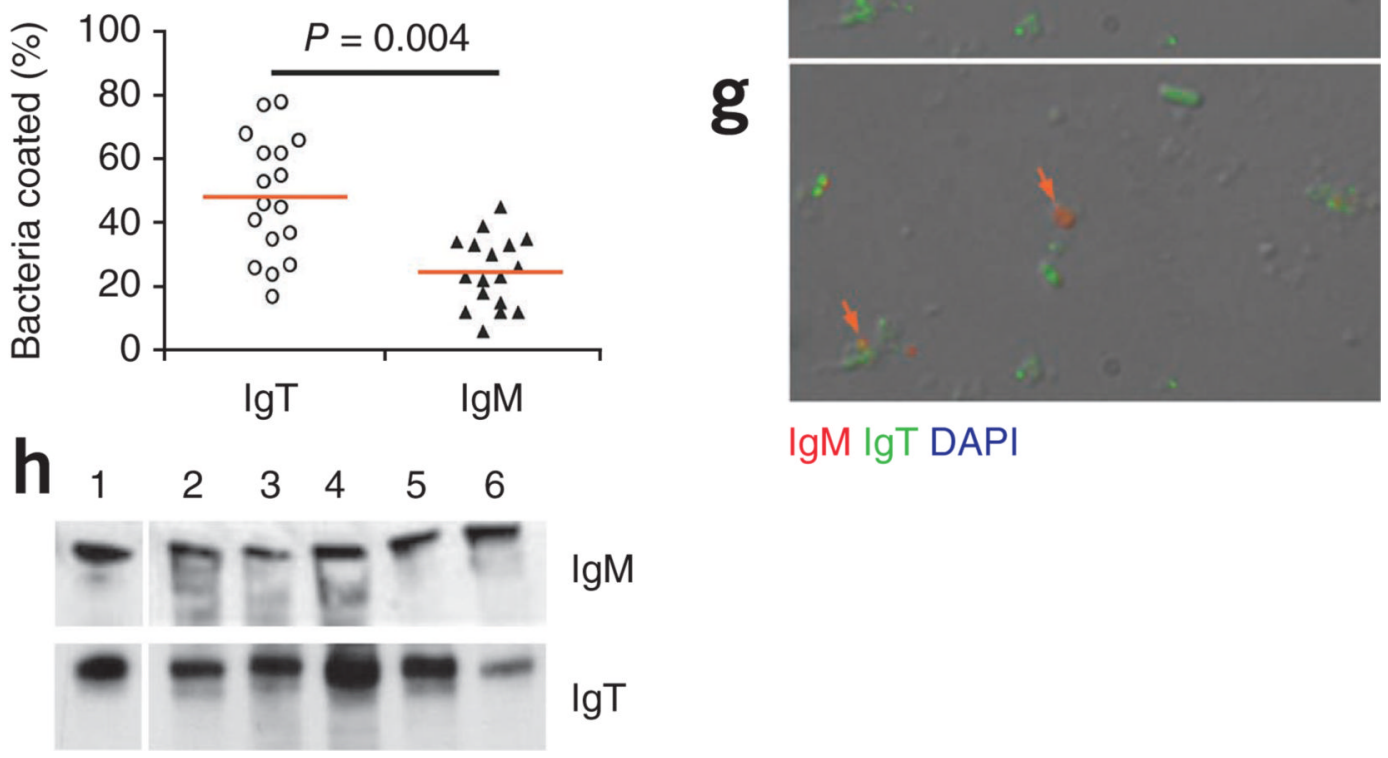

$\lg M \operatorname{Ig} T$ DAPI

Figure 7.

Most trout gut luminal bacteria are predominantly coated with IgT. (a,b) Staining of propidium iodide-positive trout gut lumen bacteria $\left(3 \times 10^{4}\right)$ with anti-IgT (a; solid lines) or anti-IgM (b; solid lines) or their respective isotype-matched control antibodies (shaded histograms). (c) Coating of bacteria with IgT or IgM. Each symbol represents an individual fish $(n=17)$; red horizontal lines indicate the median. $P$ value, nonparametric MannWhitney test. (d-g) Differential interference contrast images of luminal bacteria stained with a DAPI-Hoeschst solution (blue; d), anti-IgM (red; e) or anti-IgT (green; f), or merged IgT and IgM staining (orange; g). Isotype-matched control antibody staining, Supplementary 
Figure $5 \mathrm{f}$,g. Orange arrows indicate bacteria stained for both IgT and IgM. Scale bar, $5 \mu \mathrm{m}$. (h) Immunoblot analysis of IgT and IgM on luminal bacteria: lane 1, $0.2 \mu \mathrm{g}$ purified IgM or IgT; lanes 2-6, luminal bacteria ( $n=5$ fish). Data are representative of at least five independent experiments. 
a

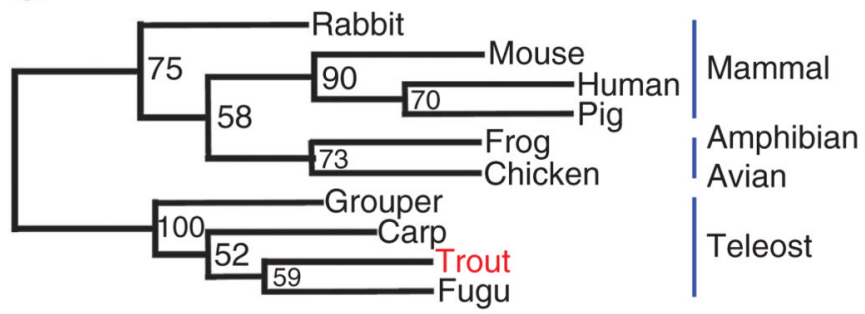

b
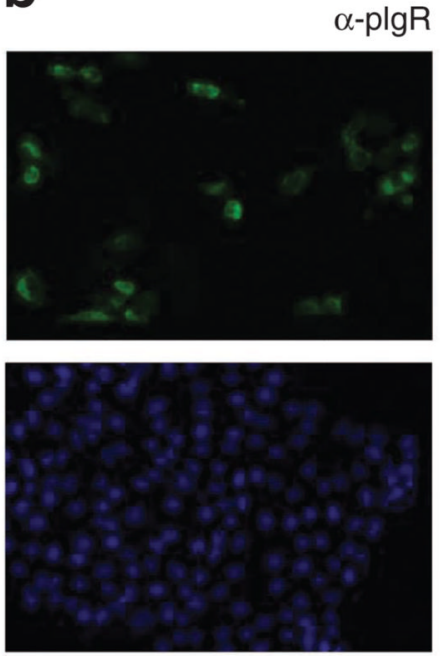

DAPI
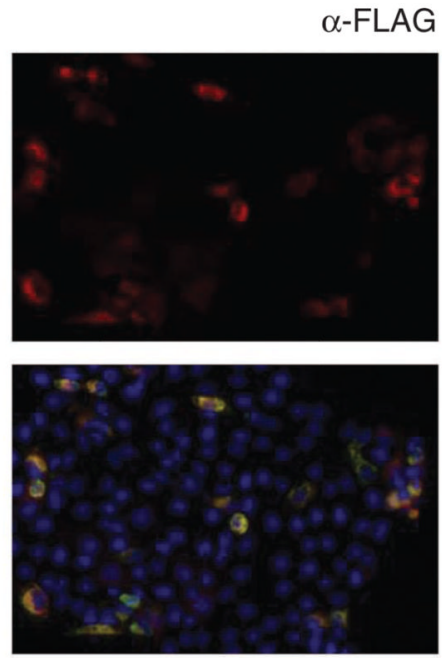

Merge
C
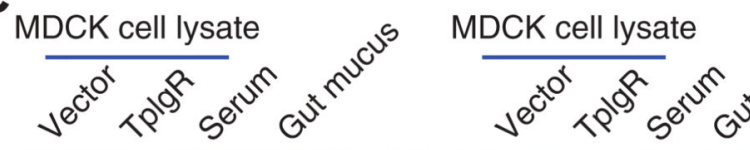

(kDa)

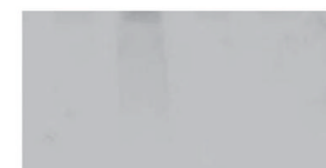

-198.4-

$-125.2-$

$-88.8=$

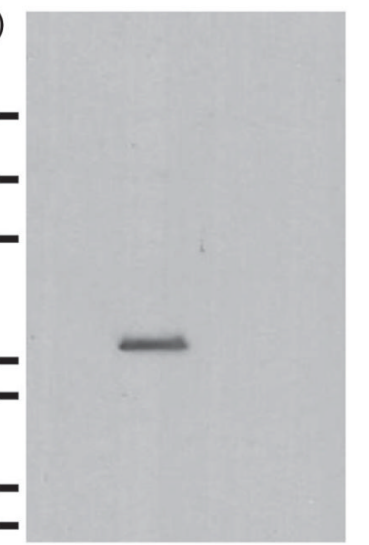

$\alpha$-plgR

- 7.0 -

$\alpha$-Flag
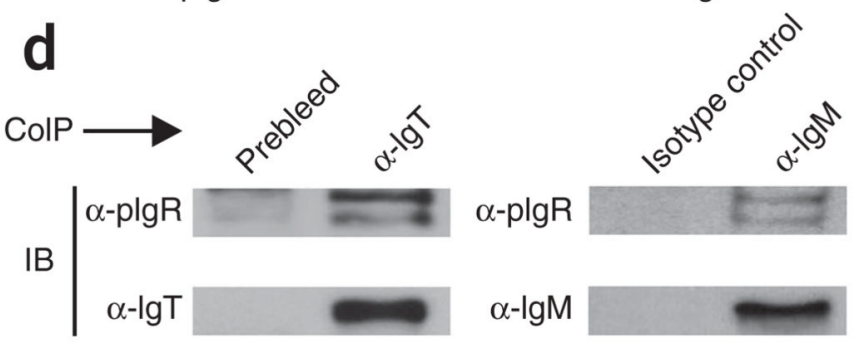

Figure 8.

Gut mucus IgT and IgM associate with a trout pIgR. (a) Phylogenetic analysis of trout pIgR, constructed on the basis of the amino acid sequences of domain 5 from all $\mathrm{pIgR}$ sequences used. Numbers in diagram (percent) represent 1,000 bootstrap replications. GenBank accession numbers: human (Homo sapiens), NM_002644); mouse (Mus musculus), NM_011082; rabbit (Oryctolagus cuniculus), NM_001171045; pig (Sus scrofa), NM_214159; chicken (Gallus gallus) NM_001044644; African clawed frog (Xenopus laevis), EF079076; rainbow trout (Oncorhynchus mykiss), FJ940682; fugu (Takifugu rubripes), AB176853; common carp (Cyprinus carpio), GU338410; and orange-spotted grouper (Epinephelus coioides), FJ803367. (b) Immuno-fluorescence microscopy of trout pIgR expressed on MDCK cells transfected with a plasmid encoding Flag-tagged trout pIgR and stained with rabbit antibody to trout $\mathrm{pIgR}$ ( $\mathrm{a}-\mathrm{pIgR}$; green), mouse anti-Flag (a-Flag; red) and DAPI (blue). Original magnification, $\times 20$. (c) Immunoblot analysis of trout $\mathrm{pIgR}$ in cell lysates $(5 \mu \mathrm{g})$ from MDCK cells transfected with empty plasmid (Vector) or plasmid encoding Flag-tagged trout pIgR (TpIgR) and in serum $(\sim 2 \mu \mathrm{g})$ and gut mucus $(\sim 2 \mu \mathrm{g})$, separated by SDS-PAGE under reducing conditions. (d) Coimmunoprecipitation (CoIP) of tSC from gut mucus with rabbit anti-IgT or mouse anti-IgM, followed by immunoblot analysis (IB) under reducing conditions (tSC detection) or nonreducing conditions (IgT and IgM detection) with anti-pIgR, anti-IgT or anti-IgM; IgG purified from serum obtained from rabbits before immunization (Prebleed) and mouse IgG1 (Isotype control) serve as negative controls for rabbit anti-IgT and mouse anti-IgM, respectively. Data are representative of at least three independent experiments. 